\section{Islamic Banking and Finance Review} =IBFe

Awareness and Knowledge of Fintech among Islamic Banking and Finance Students in Pakistan
Hassnian Ali

Faculty of Islamic Economics and Finance, Universiti Islam Sultan Sharif Ali, Bandar Sri Begawan, Brunei Darussalam.

Hussnain756@gmail.com

Hadia Saqib Hashmi

School of Islamic Economics, Business and Finance, SIEBF, Minhaj University Lahore, Pakistan.

Muhammad Waqas Shahid School of Islamic Economics, Business and Finance, SIEBF, Minhaj University Lahore, Pakistan.
Mohammad Zaki Zain

Faculty of Islamic Economics and Finance, Universiti Islam Sultan Sharif

Ali, Bandar Sri Begawan, Brunei

Darussalam.

Muhammad Hassan Abbas

School of Islamic Economics, Business and Finance, SIEBF, Minhaj University Lahore, Pakistan.

Usman Tariq

School of Islamic Economics, Business and Finance, SIEBF, Minhaj University Lahore, Pakistan.

\section{Research Paper Information:}

\section{Jo cite this article}

Ali, H., Zain, M. Z., Hashmi, H. S., Abbas, M. H., Shahid, M. W., \& Tariq, U. (2018). Awareness and knowledge of fintech among Islamic banking and finance students in Pakistan. Islamic Banking and Finance Review, 5, 02-22. $\underline{\text { Crossref }}$

\begin{tabular}{|c|c|}
\hline \multicolumn{2}{|c|}{ Atccess this article online } \\
\hline & \\
\hline & \\
\hline
\end{tabular}

\section{Contact Qnformation}

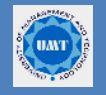

INSTITUTE OF ISLAMIC BANKING (IIB) UNIVERSITY OF MANAGEMENT AND TECHNOLOGY
Volume 5

ISSN (E):

1440-H/ 2018

ISSN (P):

2413-2977

2221-5239

\section{Journal do}

https:Ildoi.org110.32350libfr

Issue do:

https://doi.org/10.32350/ibfr.2018.05

Journal :i:

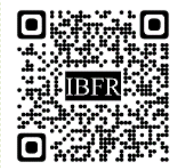

๖

This is an Open Access Journal

\section{Published By}

Institute of Islamic Banking

University of Management and

Technology (UMT)

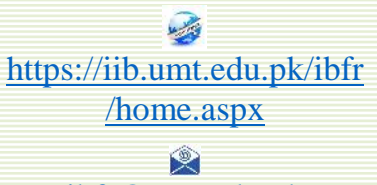

ibfr@umt.edu.pk

This article is distributed under the terms of Creative Commons

Attribution - Share Alike 4.0

International License.

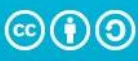

Attribution-ShareAlike 4.0 International (CC BY-SA 4.0)

\section{Indexing Partner}

\section{Crossref}

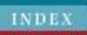

ISLAM

Crossref

Econli

\section{त्राप

INDEX COPERNICUS
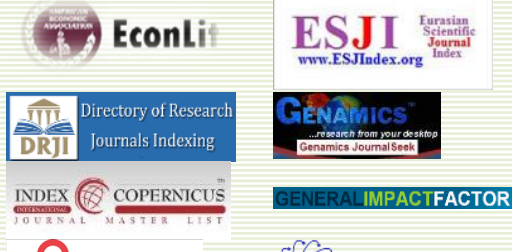

$R \oslash A D \equiv$

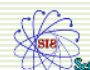

For more detail, click here 


\title{
Awareness and Knowledge of Fintech among Islamic Banking and Finance Students in Pakistan \\ Hassnian $\mathrm{Ali}^{1 *}$ \\ Mohammad Zaki Zaini ${ }^{2}$ \\ Hadia Saqib Hashmi ${ }^{3}$ \\ Muhammad Hassan Abbas ${ }^{4}$ \\ Muhammad Waqas Shahid ${ }^{5}$ \\ Usman Tariq ${ }^{6}$
}

\begin{abstract}
Purpose: The paper aims to investigate the level of awareness of Islamic banking and finance students about the concepts and terms frequently used in Fintech. The impact of the demographics of respondents on their level of knowledge about Fintech is also analyzed.

Design/methodology/approach: Descriptive statistics are used to analyze the level of awareness and knowledge of students regarding Fintech. Multiple linear regression method is used to analyze the impact of the demographics of respondents on their level of awareness and knowledge about the concepts and terms used in Fintech.

Findings: Fintech emerged around the globe and reached its peak in recent years. The students of Islamic banking and finance industry cannot overlook this phenomenon and they need to be aware of this innovative and emerging industry. Originality/Value: This paper draws the attention of academia including students, researchers, pen wielders and also of the practitioners of Islamic finance industry towards the dynamic area of Fintech and its applications that has not received enough attention so far. Thus, academia and industry may adopt an appropriate strategy regarding this issue.
\end{abstract}

Keywords: awareness, knowledge, Fintech, Islamic banking and finance, students.

${ }^{1}$ Faculty of Islamic Economics and Finance, Universiti Islam Sultan Sharif Ali, Bandar Sri Begawan, Brunei Darussalam.

${ }^{2}$ Faculty of Islamic Economics and Finance, Universiti Islam Sultan Sharif Ali, Bandar Sri Begawan, Brunei Darussalam.

${ }^{3}$ School of Islamic Economics, Business and Finance, SIEBF, Minhaj University Lahore, Pakistan.

${ }^{4}$ School of Islamic Economics, Business and Finance, SIEBF, Minhaj University Lahore, Pakistan.

${ }^{5}$ School of Islamic Economics, Business and Finance, SIEBF, Minhaj University Lahore, Pakistan.

${ }^{6}$ School of Islamic Economics, Business and Finance, SIEBF, Minhaj University Lahore, Pakistan.

* Corresponding Author Email: Hussnain756@gmail.com 


\section{Introduction}

Fintech Industry is growing at an exponential rate which has led to the emergence of innovative business models. Advance technologies like Block chain, cloud computing, internet of things (IoT's), artificial intelligence (AI), and robo advisors have matured enough to create disruption in different industries like healthcare and manufacturing industry. These technologies also have a great potential to disrupt and also to support and accelerate the operations of banking and finance irrespective of conventional or Islamic finance industry. The most active areas of Fintech are data and analytics, artificial intelligence, digital payments, digital currencies, crowdfunding and other forms of peer to peer (P2P) financing. King (2010) forecasted that banks will have a very different organizational structure in future. He further posited that the entire customer facing organization and supporting platform needs to change radically.

We live in a world where being connected is not only an expectation, rather it has become a part and parcel of our day-to-day lives. We use multiple electronic devices simultaneously. We have smartphone (s), PC, tablet, web-enabled TV to stream content, gaming devices connected to the internet and more, all at the same time. So, we live in a hyper-connected world in this era of internet and 5G.

As customer expectations are changing, companies are forced to adapt. It is expected that till 2020, companies must focus on using big data to form a single source of truth and making customer decisions and intelligence accessible throughout the enterprise. In future, customers will want to do business with firms and companies that offer a consistent, informed and greater experience across all channels of communication, taking into consideration that different customers will have different preferences. Customers will want and expect to interact using their preferred method (Walker, 2016). According to the Mobile Economy Report 2016, the year 2015 has been a year of continued growth in the mobile industry, with more than 7.6 billion mobile connections (representing 4.7 billion unique subscribers) and operating revenues of more than \$1 trillion (GSMA, 2016). According to Pew research center, two-thirds of people worldwide are using the internet (Poushter, 2016).

Pakistan Telecommunication Authority (PTA) has recently reported that the number of annual cellular subscribers by March 2017 has exceeded 139 million (70\% of population) (Pakistan Telecommunication Authority PTA, 2017). According to GSMA report, Pakistan will have 17 million new unique subscribers by 2020 (GSMA, 2017). The percentage of mobile broadband penetration has also improved from 3\% to 16\% (PTA, 2016). This shows the improvement in the adoption of mobiles and internet among Pakistanis. (Karandaaz Pakistan \& Fin Surgents, 2017) provided a comprehensive study with the title "Seeding Innovation: A framework on rotting Fintechs in Pakistan" based on primary data 
collected through face-to-face interviews with 57 senior executives and 3,000 surveys with professionals from Fintechs, microfinance and commercial banks, insurance, incubators, mobile financial services providers, startups, and telecom and technology companies. $92 \%$ senior executives and $80 \%$ middle managers in this Fintech survey agreed that Fintech not only offers the means for digitization but also has a significant role to play in emerging markets with low financial inclusion. This research also illustrates that there is a nascent ecosystem of Fintech existing in Pakistan but the gaps and hindrances in numerous information areas hamper the development and flourishing of the Fintech ecosystem in Pakistan. The main hindrance and the big information gap highlighted in this case study of Pakistan remains the lack of awareness and understanding regarding Fintech industry and the services and value that it offers in emerging markets like Pakistan.

It is a fact that Islamic banking and finance researchers and students have recently started to explore the emerging industry of Fintech with reference to Islamic banking and finance. There are some scholarly studies available with regard to the practice of Fintech within Islamic financial institutions published in the second half of 2017. (FINOCRACY and MIRAKHOR, 2017) provide a view on how Fintech can accelerate the adoption of risk sharing Islamic finance and focus on the Block chain technology and its potential in the enhancement of adoption of risk sharing finance.

Another study done by Lacasse, Lambert, \& Khan (2017) focused on the Block chain technology and explored the possibility of using this technology for the assurance of Shariah compliance in Islamic finance industry. We have seen some general articles on different blog sites, social sites, magazines and newspapers from different authors like (Abdullah, 2017; Hasan, 2017; Mohamed, 2017; Munshi, 2017). These studies discuss different topics, like smart contracts in Islamic finance, Fintech opportunity or threat for Islamic finance, Fintech for Islamic finance, Fintech is a game changer for Islamic finance etc.

This paper aims to investigate the level of awareness of the Islamic banking and finance students about concepts and terms frequently used in Fintech. The impact of the demographics of respondents on the level of their knowledge and awareness of the terms and concepts about Fintech will also be analyzed.

The remainder of this paper is organized as follows. Firstly, there is an introduction of Fintech industry and its sub-segments. This part provides the definition of Fintech and its sub-segments embellished with a short explanation and facts and figures related to them. This section of introduction of Fintech industry is followed by the methodology section that describes the method of investigation to attain the aims of this study. Next, the findings and discussion section outlines the findings from the survey and also discusses the results 
concluded from the statistical analysis of the data. Finally, the section on conclusion and recommendation provides the final words on this research along with some recommendations.

\section{Problem Statement}

History has witnessed four stages of industrial revolution. The first industrial revolution used steam power and water to mechanize and increase production. The second used electric power to create the bulk production. The third used advanced electronics and information technology to make the production autonomous. Now, we are witnessing the second phase of the third Industrial revolution; the digital revolution that started and has been going on since the middle of the last century. It is typified by a fusion of technologies and cyberphysical systems that are blurring the lines between the economic, physical, biological, and digital spheres.

In the post-industrial stage i.e. 4, also known as technological revolution era, Fintech has become one of the most dynamic, engaging, and energetic segments of the financial services marketplace. New and innovative Fintech business models exclusively offer one or more specific financial products or services in an automated way through the use of the internet and digital channels. By adopting digital channels, they unleash the various financial products and services traditionally served by service providers such as formal incumbent banks, brokers or investment managers. Here, for example, robo-advisers offer automated investment advice. Equity crowd funding platforms intermediate share placements, peer-to-peer lending platforms intermediate loans, and social trading platforms offer brokerage and investing services. Emerging and advanced technologies such as machine learning, artificial intelligence, cognitive computing, and distributed ledger technologies (DLT) can be used to supplement both Fintech's new entrants and traditional incumbents and they have the potential to materially change the financial services industry. (International Organization of Securities Commissions (IOSCO), 2017). According to World Bank (2016) report, Fintech can provide access to financial solutions for an estimated two billion adults who are currently unbanked.

Fintech is growing at an exponential rate which leads to the emergence of innovative business models. The segments of Fintech that attracted the most investments in 2016 were Insurtech with $\$ 2.2$ billion, followed by Direct Lending with $\$ 1.9$ billion and $\mathrm{P} 2 \mathrm{P}$ lending ( $\$ 1.1$ billion). In the infrastructure and enabling technologies category, main investments went into business tools (\$697 million) a strong sign of digital transformation of enterprises and crypto currencies ( $\$ 374$ million) ( $\mathrm{Su}, 2016)$. 
Fintech has become a prominent emerging industry which is revolutionizing the overall banking and finance industry. The upshot and gist of the above discussion leads to the problem statement that concerns the level of awareness and knowledge of Islamic banking and finance students about this emerging industry. The conjecture of the study is that the lack of awareness and knowledge of this emerging industry in the stakeholders of Islamic financial industry including researchers, students of Islamic finance, bankers and practitioners etc. can result into disruption and is dwindling the prospects of future growth of Islamic finance industry.

\section{Fintech Industry and its Sub-segments}

After attempting the analysis of 200 scholarly articles using the term Fintech and covering a period of more than 40 years, Schueffel, (2016) provides the definition of Fintech "Fintech is a new financial industry that applies technology to improve financial activities".

This term was used for the first time by Bettinger, (1972) in his writing "FINTECH: A Series of 40 Time Shared Models Used at Manufacturers Hanover Trust Company." The most famous origin of the term can be found and traced to the early 1990s and referred to as the "Financial Services Technology Consortium", a project which was started by Citigroup in order to assist technological cooperation efforts. Santarelli (1995) cited many studies on technological innovation and economic advancement conducted during the 1980s and 1990s, which showed that economic development can be enhanced and reinforced by the fusion of new technologies. However, it is only since 2014 that this sector has attracted the attention of industry participants, regulators, and consumers alike.

Cloud computing, big data and analytics, developers on demand, social media, an open app store for distribution and Block chain can enable rapid technology adoption and deployment in the financial services industry especially in the Fintech sector and in particular in the payment industry. These technologies could leapfrog antiquated payment mechanisms and systems in several areas such as cross-border payments. Additionally, the use of Bluetooth, NFC, and QR codes in contactless merchant based payments is also a strong threat to the existing and present payment models (PricewaterhouseCoopers, 2016).

Crowd funding is a term that refers to the practice of generating funds or capital investments for a reasonable cause, project, or enterprise by getting funds from many individuals or organizations. Crowd funding is adopted when an innovative and new idea, that has the potential to generate revenue and create jobs, requires financial support to become a reality. Crowd funding mostly takes place on crowd funding platforms (CFPs) which are internet-based platforms that 
connect fundraisers to funders with the objective of funding a particular campaign, typically by many individuals (Belleflamme et al., 2015).

These crowd funding platforms provide access to funds and capital for the segment of population that cannot have an easy access to it through traditional means. The analysts forecast the global crowd funding market to grow at a CAGR of 26.87\% during 2016-2020 (Research and Markets, 2016). Block chain is a public ledger of business transactions. A Block chain network works as an intermediator in a decentralized system for the exchange of assets and information. There are two main technology components which are 'peer-to-peer' or shared data storage and public-key cryptography (Mainelli and Milne, 2016).There are different kinds of potential and existing activities in the Block chain revolution which are broken down into three categories, Block chain 1.0, 2.0, and 3.0. Block chain 1.0 refers to the deployment of crypto currencies in applications related to cash, such as remittance, currency transfer, and digital payment systems. Block chain 2.0 refers to contracts, the entire ballet of economic, financial, and market applications using the Block chain technology that is more extensive than simple cash transactions including stocks, bonds, futures, smart property, loans, titles, mortgages, and smart contracts. Block chain 3.0 refers to Block chain applications beyond finance, currency, and markets particularly in the areas of government, literacy, science, health, art, and culture (Swan, 2015). Accenture reports that Block chain is one of the most talked about topic in the present financial services industry. $90 \%$ banks executives are interested in Block chain and currently their banks are exploring its use in the payment industry. Moreover, this report also highlights the benefits of using this technology in payment industry. These benefits include lower frictionless cost, shorter settlement time, reduced number of errors, new revenue opportunity, and lower administrative cost (Accenture, 2016).

Cloud computing has become an emerging, dynamic and most discussable topic in both academia and industry. The U.S. National Institute of Standards and Technology (NIST) has defined it as "as a model for enabling convenient, ondemand network access to a shared pool of configurable computing resources that can be rapidly provisioned and released with minimal management efforts". (Hawes, 2010). In Tech Target's forecast, $80 \%$ financial services institutions will run on hybrid cloud architecture by 2018 (TechTarget, 2016). A research firm International Data Corp (IDC) defines big data as "the intelligent economy produces a constant stream of data that is being monitored and analyzed. Social interactions, simulations, mobile devices, facilities, equipment, $R \& D$, and physical infrastructure all contribute to the flow. In aggregate, this is what is called Big Data" (International Data Corp. (IDC), 2012).

The emerging firms called Fintechs are leveraging client algorithms and information to develop automated portfolio allocation and investment 
recommendations tailored to individual customers. They have coined the term "robo-advisors". Clients can easily access robo-advice through digital user channels for low fees and sometimes free of cost (Deloitte United States, 2016). Robo-advisors have the ability to eliminate behavioral biases and handle routine account maintenance without human involvement. Robo-advisors quickly attained market traction, overseeing $\$ 19$ billion by the end of 2014. KPMG and CGI forecast that the number will be hitting \$2 trillion in assets by 2020 (Patpatia \& Association, 2016). Artificial intelligence (AI) in this digital era has also become a hot topic for some time now, with many talking about the advantages that it can bring to the financial services industry. AI can help banks in their anti-money laundering AML or employee misconduct detection efforts by replacing costly functions that are currently performed manually by humans (Arslanian, 2016). Internet of Things (IoT) is an emerging and new paradigm in the science of computers and technology in a general sense. In the past few years, it has invaded our lives and is getting ground as one of the most promising technologies. According to the European Commission, IoT involves "Things having identities and virtual personalities operating in smart spaces using intelligent interfaces to connect and communicate within social, environmental, and user contexts" (Atzori et al., 2010). The number of objects able to record and transmit data to other objects is continually growing. It is forecasted that the number of devices connected to the internet will increase from 10 billion today to 50 billion by 2020 (Payvision, 2016). The IoT could give retailers, sellers and their banks access to real-time detail they need regarding things and goods in transit (Santander, 2015).

\section{Methodology}

This section explains the method of analysis and investigation on which this study is based and which is geared to achieve the abovementioned objectives.

\subsection{Questionnaire Design}

A self-developed questionnaire was used to gather primary data from the respondents. There were three parts of the questionnaire. The first part had the title 'awareness and knowledge of Fintech' and encompassed 09 questions. The answers were graded at a five-point Likert scale with the options ranging from "Not at all aware" to "Extremely aware". The second part of the questionnaire was composed of only 3 questions which dealt with the opinion of students about the curriculum and their willingness to get the appropriate the knowledge of Fintech. The third and final part of the questionnaire was about the demographics of the respondents including their age, university, and gender etc.

\subsection{Sample Size and Collection of Data}

Fieldwork was conducted and the questionnaire was distributed among the Islamic banking and finance students of three selected universities including 
University of Management and Technology (UMT), Lahore, Minhaj University, Lahore and International Islamic University Islamabad (IIUI). More than 80 questionnaires were distributed but only 50 students recorded their responses.

\subsection{Model Specifications}

Descriptive statistics was used to analyze the level of knowledge and awareness of students regarding Fintech. Multiple linear regression method was used to analyze the impact of the demographics of respondents on their level of awareness and knowledge about the concepts and terms used in Fintech. Numerous researches have been conducted regarding the awareness of different variables among students of different faculties in various countries in which the regression method has been used as a tool of investigation (see: Ishemoi, 2007; Mohamed Musse, 2015; Noonari, 2015; Saiti, 2015).

The model used in this study is as follows,

$Y=\alpha+\beta 1$ age $+\beta 2$ university $+\beta 3$ gender $+\beta 4$ degree $+\beta 5$ area of study

$Y=$ Dependent variable and in the model it denotes students' score regarding

awareness and knowledge of Fintech.

$\alpha=$ the intercept term

Age $=$ Dummy variable; it is one if the respondent's age is above 25, zero otherwise.

University = Dummy variable; it is one if the respondent from UMT, zero

otherwise.

Gender = Dummy variable; it is one if the respondent is female, zero otherwise.

Degree $=$ Dummy variable; it is one if the respondent a postgraduate student, zero otherwise.

Area of interest $=$ Dummy variable; it is one if the respondent's area of interest is Islamic finance, zero otherwise.

\section{Findings and Discussion}

\subsection{Demographics}

Table 1

Demographic Variables of Respondents

\begin{tabular}{lll}
\hline Gender & No of Respondents & Proportion \\
Male & 19 & $38 \%$ \\
\hline Female & 31 & $62 \%$ \\
Total & 50 & $100 \%$ \\
Age & No of Respondents & Proportion \\
30 and Less than 30 (Years) & 35 & $70 \%$ \\
Above 30 & 15 & $30 \%$ \\
Total & 50 & $100 \%$ \\
Area of Interest & No of Respondents & Proportion \\
\hline
\end{tabular}




\begin{tabular}{lll}
\hline Islamic Banking and Finance & 44 & $88 \%$ \\
Others (Economics, Math) & 06 & $12 \%$ \\
Total & 50 & $100 \%$ \\
Affiliation & No of Respondents & Proportion \\
Minhaj University & 15 & $30 \%$ \\
UMT & 25 & $50 \%$ \\
IIUI & 10 & $20 \%$ \\
Total & 50 & $100 \%$ \\
Degree & No of Respondents & Percentage \\
Undergraduates & 22 & $44 \%$ \\
Postgraduates (MS+ Ph.D.) & 28 & $56 \%$ \\
Total & 50 & $100 \%$ \\
\hline
\end{tabular}

The figures given in table1 show that the majority of respondents $(62 \%)$ are female. Only $28 \%$ respondents are male. $70 \%$ respondents are 30 years old or less while $30 \%$ respondents are above 30 . This table also shows that the majority of students $(88 \%)$ have an interest in the field of Islamic finance and only $12 \%$ showed interest in other areas like economics, business, math etc. Two other important pieces of information that could be derived from table 1 include the academic affiliation and degree of the respondents. The majority of respondents $(50 \%)$ are from University of Management and Technology (UMT), Lahore, followed by respondents from Minhaj University, Lahore (30\%) and from International Islamic University Islamabad (IIUI) (20\%), respectively. 44\% respondents are undergraduate students and $56 \%$ percent are postgraduate students.

\subsection{Awareness and Knowledge of Fintech}

1. Are you familiar with the term Fintech?

Table 2

Are you familiar with the term Fintech

\begin{tabular}{lcccccc}
\hline Familiarity & $\begin{array}{c}\text { Not } \\
\text { at all }\end{array}$ & Slightly & Somewhat & Moderately & Extremely & Total \\
\hline No of Respondents & 24 & 9 & 7 & 8 & 2 & 50 \\
Percentage & $48 \%$ & $18 \%$ & $14 \%$ & $16 \%$ & $4 \%$ & $100 \%$ \\
\hline
\end{tabular}

This table shows that only $2 \%$ respondents are very familiar with the term Fintech, $16 \%$ are moderately familiar with this term, $14 \%$ are not sure about this term and $18 \%$ have very little familiarity with Fintech. The majority of respondents (48\%) have no idea and knowledge of this term.

2. Are you familiar with Block chain and smart contracts and their use in banking and finance industry? 
Table 3

Are you familiar with Block chain and smart contracts and their use in banking and finance industry

\begin{tabular}{lcccccc}
\hline Block chain & $\begin{array}{c}\text { Not } \\
\text { at all }\end{array}$ & Slightly & Somewhat & Moderately & Extremely & Total \\
\hline No of Respondents & 29 & 7 & 4 & 5 & 5 & 50 \\
Percentage & $58 \%$ & $14 \%$ & $8 \%$ & $10 \%$ & $10 \%$ & $100 \%$ \\
\hline
\end{tabular}

This table shows that $10 \%$ respondents are extremely aware and another $10 \%$ are moderately aware about Block chain and smart contracts and their use in banking and finance industry. $8 \%$ respondents have somewhat awareness and $14 \%$ respondents are only slightly aware. The majority of respondents $(58 \%)$ have no knowledge about Block chain and smart contracts and their use in banking and finance industry.

3. To what extent you know about neo-banking or digital-only banking?

Table 4

To what extent you know about neo-banking or digital-only banking

\begin{tabular}{lcccccc} 
Neo-Banking & $\begin{array}{c}\text { Not } \\
\text { at all }\end{array}$ & Slightly & Somewhat & Moderately & Extremely & Total \\
\hline No of Respondents & 22 & 8 & 7 & 6 & 7 & 50 \\
Percentage & $44 \%$ & $16 \%$ & $14 \%$ & $12 \%$ & $14 \%$ & $100 \%$ \\
\hline
\end{tabular}

This table shows that $14 \%$ respondents have an extreme level of awareness about neo-banking, $12 \%$ are moderately aware and another $14 \%$ have some know how about it. This table elucidates that $14 \%$ respondents are extremely aware about digital-only banking, $12 \%$ know moderately about it and 14\% know somewhat. 16\%respondents have a very low level of knowledge about neobanking and again the majority of respondents (44\%) have no knowledge and their level of awareness is zero.

4. Do you know about crowd funding?

Table 5

Do you know about crowd funding

\begin{tabular}{lcccccc}
\hline Crowd funding & $\begin{array}{c}\text { Not } \\
\text { at all }\end{array}$ & Slightly & Somewhat & Moderately & Extremely & Total \\
\hline No of Respondents & 34 & 5 & 2 & 6 & 3 & 50 \\
Percentage & $68 \%$ & $10 \%$ & $4 \%$ & $12 \%$ & $6 \%$ & $100 \%$ \\
\hline
\end{tabular}

This table highlights that only $6 \%$ respondents are fully aware about crowd funding, $12 \%$ have a moderate level of knowledge and $4 \%$ respondents know somewhat about it. $10 \%$ percent respondents have very little knowledge of crowd 
funding and the majority of respondents (68\%) are totally unaware about this phenomenon.

5. Do you know about cloud computing and its adoption in banking and finance industry?

Table 6

Do you know about cloud computing and its adoption in banking and finance industry

\begin{tabular}{lcccccc}
\hline Cloud Computing & $\begin{array}{c}\text { Not } \\
\text { at all }\end{array}$ & Slightly & Somewhat & Moderately & Extremely & Total \\
\hline No of Respondents & 32 & 7 & 3 & 5 & 3 & 50 \\
Percentage & $64 \%$ & $14 \%$ & $6 \%$ & $10 \%$ & $6 \%$ & $100 \%$ \\
\hline
\end{tabular}

This table explains that merely $6 \%$ respondents are extremely aware about cloud computing and its adoption in banking and finance industry. $10 \%$ are moderately aware and 6\% know somewhat about it. 14\% respondents have very little knowledge about this phenomenon and the majority of respondents (64\%) have no idea about cloud computing and its adoption in banking and finance industry.

6. Are you aware about big data analytics and its use in banking and finance industry?

Table 7

Are you aware about big data analytics and its use in banking and finance industry

\begin{tabular}{lcccccc}
\hline Big Data & $\begin{array}{c}\text { Not } \\
\text { at all }\end{array}$ & Slightly & Somewhat & Moderately & Extremely & Total \\
\hline No of Respondents & 23 & 9 & 4 & 8 & 6 & 50 \\
Percentage & $46 \%$ & $18 \%$ & $8 \%$ & $16 \%$ & $12 \%$ & $100 \%$ \\
\hline
\end{tabular}

This table shows that $12 \%, 16 \%$ and $8 \%$ of respondents are extremely, moderately and somewhat aware about big data analytics and its use in banking and finance industry, respectively. $18 \%$ respondents are slightly aware and the majority of respondents (46\%) have no knowledge about big data analytics and its use in banking and finance industry.

7. Do you have knowledge about robo advisors in banking and finance industry? 
Table 8

Do you have knowledge about robo advisors in banking and finance industry

\begin{tabular}{lcccccc}
\hline Robo Advisors & $\begin{array}{c}\text { Not } \\
\text { at all }\end{array}$ & Slightly & Somewhat & Moderately & Extremely & Total \\
\hline No of Respondents & 35 & 4 & 6 & 3 & 2 & 50 \\
Percentage & $70 \%$ & $8 \%$ & $12 \%$ & $6 \%$ & $4 \%$ & $70 \%$ \\
\hline
\end{tabular}

This table highlights that only $4 \%$ respondents are fully aware about robo advisors in banking and finance industry, $6 \%$ have a moderate level of knowledge and $12 \%$ are somewhat aware about robo advisors. $8 \%$ respondents have very little knowledge and the majority of respondents (70\%) are totally unaware about robo advisors in banking and finance industry.

8. Do you know about artificial intelligence AI and its usage in banking and finance?

Table 9

Do you know about artificial intelligence AI and its usage in banking and finance

\begin{tabular}{lcccccc} 
AI & $\begin{array}{c}\text { Not } \\
\text { at all }\end{array}$ & Slightly & Somewhat & Moderately & Extremely & Total \\
\hline $\begin{array}{l}\text { No of Respondents } \\
\text { Percentage }\end{array}$ & $50 \%$ & 10 & 6 & 6 & 3 & 50 \\
\hline
\end{tabular}

This table shows that only $6 \%$ respondents are extremely aware about artificial intelligence and its use in banking and finance industry. 12\% respondents are moderately aware and another $12 \%$ have somewhat awareness about it. $14 \%$ respondents are slightly aware and the majority of respondents (50\%) have no knowledge about artificial intelligence and its use in banking and finance industry.

9. Do you know about Internet of things (IoT's) and its usage in finance industry?

Table 10

Do you know about Internet of things (IoT's) and its usage in finance industry

\begin{tabular}{lcccccc}
\hline IoT's & $\begin{array}{c}\text { Not } \\
\text { at all }\end{array}$ & Slightly & Somewhat & Moderately & Extremely & Total \\
\hline No of Respondents & 27 & 9 & 5 & 4 & 5 & 50 \\
Percentage & $54 \%$ & $18 \%$ & $10 \%$ & $8 \%$ & $10 \%$ & $100 \%$ \\
\hline
\end{tabular}

This table explains that merely $10 \%$ respondents are extremely aware about internet of things and its use in banking and finance industry, $8 \%$ are moderately aware, and $10 \%$ know somewhat about it. $18 \%$ respondents are only slightly aware and 54\% have no idea about internet of things and its use in banking and finance industry. 
Table 11

Chart of All answers of Respondents

\begin{tabular}{lccccccc}
\hline Questions & $\begin{array}{l}\text { Total No of } \\
\text { Respondents }\end{array}$ & $\begin{array}{l}\text { Not at } \\
\text { all }\end{array}$ & $\begin{array}{l}\text { Slightly } \\
\%\end{array}$ & $\begin{array}{l}\text { Somewhat } \\
\%\end{array}$ & $\begin{array}{l}\text { Moderately } \\
\%\end{array}$ & $\begin{array}{l}\text { Extremely } \\
\%\end{array}$ & $\begin{array}{l}\text { Total } \\
\%\end{array}$ \\
\hline Q1 & 50 & $48 \%$ & $18 \%$ & $14 \%$ & $16 \%$ & $4 \%$ & $100 \%$ \\
Q2 & 50 & $58 \%$ & $14 \%$ & $8 \%$ & $10 \%$ & $10 \%$ & $100 \%$ \\
Q3 & 50 & $44 \%$ & $16 \%$ & $14 \%$ & $12 \%$ & $14 \%$ & $100 \%$ \\
Q4 & 50 & $68 \%$ & $10 \%$ & $4 \%$ & $12 \%$ & $6 \%$ & $100 \%$ \\
Q5 & 50 & $64 \%$ & $14 \%$ & $6 \%$ & $10 \%$ & $6 \%$ & $100 \%$ \\
Q6 & 50 & $46 \%$ & $18 \%$ & $8 \%$ & $16 \%$ & $12 \%$ & $100 \%$ \\
Q7 & 50 & $70 \%$ & $8 \%$ & $12 \%$ & $6 \%$ & $4 \%$ & $100 \%$ \\
Q8 & 50 & $50 \%$ & $20 \%$ & $12 \%$ & $12 \%$ & $6 \%$ & $100 \%$ \\
Q9 & 50 & $54 \%$ & $18 \%$ & $10 \%$ & $8 \%$ & $10 \%$ & $100 \%$ \\
Average & 50 & $56 \%$ & $15 \%$ & $10 \%$ & $11 \%$ & $8 \%$ & $100 \%$ \\
\hline
\end{tabular}

This table provides a holistic overview of the percentage of responses of 50 respondents to 09 questions. This table also shows that on average only 8\% respondents are fully aware about Fintech and its sub-segments including Block chain, cloud computing and crowd funding etc. $11 \%$ and $10 \%$ respondents are moderately and somewhat aware about Fintech and its sub-segments, respectively. $15 \%$ have very little awareness and the majority of the respondents $(56 \%)$ are completely unaware about Fintech and its sub-segments.

\subsection{Impact of Demographics on Awareness and Knowledge}

In this section, 09 questions were formulated relevant to different terms used in Fintech. Each correct answer was given the score of 1-5 (Strongly disagree $=1 .$. Strongly agree $=5$ ) that yielded a maximum score of 45 which was used as a dependent variable with 5 independent or explanatory variables including age, gender, area of study, degree, and university at 5\% level of significance.

Table 12

ANOVA results for Impact of demographics on awareness and knowledge

\begin{tabular}{llccccc}
\hline Model & & $\begin{array}{c}\text { Sum of } \\
\text { Squares }\end{array}$ & Df & $\begin{array}{c}\text { Mean } \\
\text { Square }\end{array}$ & F & Sig. \\
\hline 1 & Regression & 1335.565 & 5 & 267.113 & 4.387 & $.003^{\text {b }}$ \\
& Residual & 2679.255 & 44 & 60.892 & & \\
& Total & 4014.820 & 49 & & &
\end{tabular}

a. Dependent Variable: Awareness

b. Predictors: (Constant), Gender, Area of Study, Age, Degree, Uni 
Table 12 gives the significance value which is also denoted as $\mathrm{p}$ value. Here, in this model, the $p$ value is .003 which is less than $.005(p<. \alpha)$. It means that the model is fit and these predictors have the capacity to predict the dependent variable.

Table 13

ANOVA results for Impact of demographics on awareness and knowledge

\begin{tabular}{lcccc}
\hline Variables & Coefficients & Std. Error & t-value & Sig, \\
\hline Constant & 17.912 & 5.106 & 3.508 & .001 \\
Age & -11.607 & 3.216 & -3.610 & .001 \\
University & 8.939 & 5.912 & 1.512 & .138 \\
Gender & 1.529 & 3.682 & .415 & .680 \\
Degree & 5.496 & 4.861 & 1.131 & .264 \\
Area of & -5.406 & 3.816 & -1.417 & .164 \\
interest & .333 & & & \\
$\mathrm{R}^{2}$ & .257 & & & \\
Adjusted $\mathrm{R}^{2}$ & .003 & & & \\
Sig & & & & \\
\hline
\end{tabular}

Table 13 provides the summary of the model which is being used in this analysis. In this table, adjusted $\mathrm{R}$ value denotes that predictor variables are predicting the dependent variable, that is, awareness within the variance of $25.7 \%$.

This table also describes the coefficient, $t$ and sig values of each independent variable while keeping other variables constant. So, in this table there is only one independent variable or predictor, that is, age which has a significant value $.001<.005$. It means that this predictor has a significant impact on the dependent variable, that is, awareness. The coefficient value of this predictor is -11.607 , which shows that as the age increases the level of awareness decreases. In other words, younger students are more aware than older ones and vice versa. This can be justified because younger students are more tech savvy than older ones.

The table also shows that, surprisingly, the other four predictors (university, gender, degree and area of interest) have non-significant values (all have $p>\alpha$ ). It means that in this model these four are not predicting or showing an impact on the dependent variable, that is, awareness. The significance value of the model mentioned in tables 12 and 13 is .003, which shows the fitness of the model and the capacity of all the predictors to predict the dependent variable.

There may be some reasons and factors involved here which lead to the insignificance of the four predictors. One reason is the novelty of the topic which is Fintech. It is a very new topic in academia and Islamic finance industry, especially in Pakistan. Another reason is the smallness of data along with randomization of sample. There were only 50 respondents and the data was not 
collected from an equal number of students from each university. Table 11 shows that a high percentage of respondents $(71 \%)$ are totally unaware or have very little awareness of Fintech, irrespective of university, gender, degree and area of study. These are the factors which lead to the non-significance of the four predictors in predicting the dependent variable. But this insignificance is also meaningful in the sense that if these factors are removed then more comprehensive results can be achieved.

\subsection{Opinion of Respondents about Academic Syllabus and Their Willingness to Acquire Knowledge of Fintech}

This section encompassed only 3 questions which dealt with the opinion of students about the academic syllabus and their willingness to know Fintech.

1. Is Fintech covered in your academic syllabus?

Table 14

Is Fintech covered in your academic syllabus

\begin{tabular}{lcccccc}
\hline Syllabus & $\begin{array}{c}\text { Strongly } \\
\text { Disagree }\end{array}$ & Disagree & Neutral & Agree & $\begin{array}{c}\text { Strongly } \\
\text { Agree }\end{array}$ & Total \\
\hline No of Respondents & 21 & 15 & 6 & 5 & 3 & 50 \\
Percentage & $42 \%$ & $30 \%$ & $12 \%$ & $10 \%$ & $6 \%$ & $100 \%$ \\
\hline
\end{tabular}

This table shows that $42 \%$ and $30 \%$ respondents either strongly disagree or disagree respectively with the statement and opine that Fintech is not covered in their academic syllabus. Another $12 \%$ are not sure. $10 \%$ think that Fintech is covered in their academic syllabus. A merely $8 \%$ of respondents opine that Fintech is fully covered in their academic syllabus.

2. Do you feel that each student of Islamic banking and finance should have proper knowledge of Fintech?

Table 15

Do you feel that each student of Islamic banking and finance should have proper knowledge of Fintech

\begin{tabular}{lcccccc}
\hline Knowledge & $\begin{array}{c}\text { Strongly } \\
\text { Disagree }\end{array}$ & Disagree & Neutral & Agree & $\begin{array}{c}\text { Strongly } \\
\text { Agree }\end{array}$ & Total \\
\hline No of Respondents & 5 & 3 & 5 & 14 & 23 & 50 \\
Percentage & $10 \%$ & $6 \%$ & $10 \%$ & $28 \%$ & $46 \%$ & $100 \%$ \\
\hline
\end{tabular}

Table 15 shows that $46 \%$ and $28 \%$ respondents either strongly agree or agree respectively and think that Islamic banking and finance students must have proper knowledge of Fintech. Another 10\% respondents are not sure. $6 \%$ disagree with this statement and the remaining $10 \%$ strongly disagree. 
3. Students of Islamic Banking and Finance should take a course about Fintech.

Table 16

Students of Islamic Banking and Finance should take a course about Fintech

\begin{tabular}{lcccccc}
\hline Course & $\begin{array}{c}\text { Strongly } \\
\text { Disagree }\end{array}$ & Disagree & Neutral & Agree & $\begin{array}{c}\text { Strongly } \\
\text { Agree }\end{array}$ & Total \\
\hline No of Respondents & 4 & 1 & 5 & 16 & 24 & 50 \\
Percentage & $8 \%$ & $2 \%$ & $10 \%$ & $32 \%$ & $48 \%$ & $100 \%$ \\
\hline
\end{tabular}

Table 16 elucidates that $48 \%$ and $32 \%$ respondents either strongly agree or agree respectively with this statement and opine that Islamic banking and finance students should take a course about Fintech. Only 2\% disagree and another 8\% strongly disagree with this statement. $10 \%$ are not sure.

\section{Conclusion and Recommendations}

There is clear evidence that Fintch industry is growing at an exponential rate, which leads to the emergence of innovative business models. Advanced technologies like Blockchain, cloud computing, internet of things (IoT's), artificial intelligence (AI) and robo-advisors have become mature enough to create disruption in different industries like healthcare and manufacturing etc. These technologies have not only a great potential to disrupt but also to support and accelerate the operations of banking and finance industry irrespective of its being conventional or Islamic. The most active areas of Fintech are data and analytics, artificial intelligence, digital payments, digital currencies, crowd funding and other forms of peer to peer (P2P) financing etc.

The gist of the findings and discussion is very clear and it says that the majority of the Islamic banking and finance students in Pakistan are not well aware of Fintech. This attitude of unawareness is common among all the students irrespective of degree, area of interest, gender, age, and university. The statistical analysis clearly shows that the level of unawareness is significant among older students as compared to younger ones. This can be justified as studies show that younger students are more tech-savvy than older ones.

The findings also highlight that the majority of students believe that their academic syllabus doesn't cover the content of Fintech and its sub-segments. They also think that they need to be aware of Fintech and they should get proper knowledge of it. Finally, the majority of students also show consensus on taking a course about Fintech. This shows that students have become familiar with Fintech from this survey and also consider it important to be aware about Fintech and its sub-segments, especially in this era of digitalization. 
The study also gives the following recommendations:

The educational institutions in general and especially syllabus committee of Islamic finance departments of universities should revise the academic curriculum and design a comprehensive course on Fintech for Islamic finance students. Institutions should offer training programs and also organize workshops and seminars to promote and uplift the level of awareness of students about the new and emerging industry of Fintech. This kind of initiative and programs will enable the graduates to enhance their scope and diversify their opportunities and will allow them to compete in the changing environment of the financial industry. The students of Islamic banking and finance should acquire knowledge of Fintech themselves from different sources, such as research papers on Fintech and internet etc. The knowledge and awareness of Fintech is very important for Islamic finance students to cope with the demands of this digital era. 


\section{References}

Abdullah, O. (2017). Fintech for Islamic Finance. Retrieved January 25, 2018, from https://islmfintech.com/

Accenture. (2016). Blockchain technology: How banks are building a real-time global payment network. North America: Author.

Arslanian, H. (2016). 10 Fintech predictions for Asia in 2017: Let's talk payments. Retrieved from https://gomedici.com/10-fintech-predictions-forasia-in-2017/

Atzori, L., Iera, A., \& Morabito, G. (2010). The internet of things: A survey. Computer Network, 54(15), 2787-2805.

Crossref

Belleflamme, P., Omrani, N., \& Peitz, M. (2015). The economics of crowdfunding platforms. Information Economics and Policy, 33, 11-28.

Bettinger, A. (1972). FINTECH: A series of 40 time shared models used at manufacturers Handover Trust Company. Interfaces, 2(4), 62-63.

Deloitte United States. (2015). Robo-advisors: Capitalizing on a growing opportunity. Retrieved from https://www2.deloitte.com/content/dam/Deloitte/ us/Documents/strategy/us-cons-robo-advisors.pdf

Finocracy, A. A., Mirakhor, A., (2017). Accelerating risk sharing finance via Fintech: Nextgen Islamic Finance. Retrieved from http://www.icibif.ir/files_ site=/files /r_33_170304171220.pdf

GSMA. (2017). Mobile Economy 2017. Retrieved from https://www.gsma.com/ mea/the-mobile-economy-2017.

GSMA. (2016). GSMA Mobile Economy 2016. Retrieved from https://www.gsma. com /mobileeconomy/2016/global/

Hasan, S. B. M. (2017, December 28). Islamic Fintech - A threat for Islamic banks or an opportunity? [Blog post]. Retrieved from https://www.ethiscrowd.com/blog/islamic-fintech-and-islamic-banks/

Hawes, K. (2010). Cloud computing [WWW Document]. Retrieved November 01, 2017, from https://www.nist.gov/programs-projects/cloud-computing

IOSCO. (2017). IOSCO research report on financial technologies (FinTech). Retrieved from https://www.iosco.org/library/pubdocs/pdf/IOSCOPD554.pdf 
International Data Corp. (IDC). (2012). Worldwide big data technology and services 2012-16 forecast. Retrieved from http://www.datascienceassn.org/ sites/default/files/Worldwide \%20Big\%20Data\%20Technology\%20and\%20 Services\%202012\%20-\%202016\%20Fore cast.pdf

Ishemoi, L. J. (2007). Bank selection criteria among undergraduate students in Tanzania. African Journal of Finance and Management. 15, 33-44.

Karandaaz Pakistan. (2017, January 24). Seeding innovation - A framework for rooting FinTechs in Pakistan. Retrieved from https://karandaaz.com.pk/media-center/news-events/seeding-innovation-aframework-for-rooting-fintechs-in-pakistan/

Lacasse, R.-M., Lambert, B., \& Khan, N. (2017). Blockchain technology-Arsenal for a Shariah-compliant financial ecosystem. Retrieved from https://islamicmarkets.com/ publications/blockchain-technology-arsenal-for-ashariah-compliant-financial-ecosystem

Mainelli, M., \& Milne, A. (2016, May 9). The impact and potential of Blockchain on securities transaction lifecycle. SWIFT Institute Working Paper No. 2015007. Retrieved from SSRN: https://ssrn.com/abstract=2777404

Mohamed, H. (2017). Smart contracts in Islamic economic transactions. Retrieved from https://journal.wahedinvest.com/smart-contracts-in-islamic-economictransactions/

Mohamed, M. A. (2015). Awareness of Islamic banking products and services among non-Muslim students in selected northern universities of Malaysia. Munich, Germany: GRIN Publishing.

Munshi, U., (2017). Islamic Fintech: Wake up to the Truth [LinkedIn]. Retrieved from https://www.linkedin.com/pulse/islamic-fintech-wake-up-truth-umarmunshi

Noonari, S., Memon, I. N., Mangi, J. A., Pathan, M., Khajjak, A. K., Memon, Z.,...Pathan, A. (2015). Knowledge and perception of students regarding Islamic banking: A case study of Hyderabad Sindh Pakistan. Information and Knowledge Management, 5(7), 86-99.

Pakistan Telecommunication Authority. (2017). Telecom indicators. Retrieved January 10, 2017 from http://www.pta.gov.pk/index.php?Itemid=599

PATPATIA \& Associates. (2016). Beyond Robo-advisors: Using technology to power new methods of client advice and interaction. Retrieved from http://patpatia.com/wp-content/uploads/2016/07/Robo-Advisor-AutomatedAdvice-Platform-CGI-Patpatia-Whitepaper.pdf 
Poushter, J. (2016). Smartphone ownership and internet usage continues to climb in emerging economies. Retrieved from http://www.pewglobal.org/2016/02/22 /smartphone-ownership-and-internet-usage-continues-to-climb-inemergingeconomies/

Price Waterhouse Coopers. (2016). Payments in the Wild Tech World: Digitisation and changing customer expectations, Global FinTech Survey 2016. Retrieved from https://www.pwchk.com/en/consulting/consultingfintech-wtw-aug2016.pdf

PTA. (2016). Pakistan Telecommunication Authority: Annual Report. Islamabad: Author.

Research and Markets, 2016. Global Crowdfunding Market 2016-2020-Low penetration in developing countries restricting growth-Research and Markets. Retrieved from https://www.businesswire.com/news/home/20160203005780/ en/Global-Crowdfunding-Market-2016-2020---Penetration-Developing

Saiti, B. (2015). The awareness and attitude towards Islamic banking: A study in Malaysia. Global Review of Islamic Economics and Business. 2(3), 172-196. $\underline{\text { Crossref }}$

Santander InnoVentures. (2015). The Fintech 2.0 Paper: Rebooting financial services. Retrieved from http://santanderinnoventures.com/wpcontent/uploads/2015/06/The-Fintech-2-0-Paper.pdf

Santarelli, E. (1995). Finance and technological change: Theory and evidence. London, UK: Palgrave Macmillan.

Crossref

Schueffel, P. (2016). Taming the beast: A scientific definition of Fintech. Journal of Innovation Management. 4(4), 32-54.

Su, J. B. (2016). The Global Fintech landscape reaches over 1000 companies, \$105B In Funding, \$867B In Value: Report. Retrieved February 3, 2017, from http://www.forbes.com/sites /jeanbaptiste/2016/09/28/the-global-fintechlandscape-reaches-over-1000-companies-105b-in-funding-867b-in-valuereport/

Swan, M. (2015). Blockchain: Blueprint for a new economy. Sebastopol, USA: O'Reilly Media.

TechTarget. (2016). What does cloud computing look like in 2016? (ANZGuide). Retrieved from https://www.computerweekly.com/ehandbook/Whatdoes-cloud-computing-look-like-in-2016-ANZ-Guide 
Walker. (2016). Customers 2020: The future of B-to-B customer experience. Retrieved from https://www.walkerinfo.com/Portals/0/Documents/Knowledge \%20Center/Featured\%20Reports/WALKER-Customers2020.pdf

World Bank. (2016). Fintech and financial inclusion. Retrieved from http://pubdocs.worldbank.org/en/877721478111918039/breakout-DigiFinance -McConaghy-Fintech.pdf 